\title{
IMPROVING SPEAKING ABILITY THROUGH STORY TELLING TECHNIQUE BY USING PICTURE SERIES
}

\author{
Purwatiningsih \\ MAN 2 Madiun \\ ptm2madiun@gmail.com
}

\begin{abstract}
This research was conducted to solve the students' problems in speaking. It is to improve the students' ability in speaking through story-telling technique by using picture series in terms of content and delivery of the story. The design of this study was classroom action research which was conducted in two cycles consisting of six meetings. The subjects of this study were students of grade X-9 of MAN 2 Madiun in $2014 / 2015$ academic year. The instruments to collect the data were observation checklists, field notes, speaking task measured using scoring rubrics, and questionnaire. The finding of the study indicated that the implementation of the technique was successful in improving the students' speaking ability, since the criteria of success were achieved. Implementing the story-telling technique using picture series in teaching speaking encompasses several procedures: 1) understanding the narrative text carefully, 2) understanding grammar and difficult words, 3) employing dictions based on its context, 4) discussing the text in groups, 5) using own sentences to deliver story, 6) avoiding mistakes by having picture series, 7) understanding the message or social value of the text, and 8) giving reward to enhance motivation.
\end{abstract}

Keywords: story-telling, picture series, speaking ability

English constitutes a means of communication other than the first language, either verbal or non verbal, which is spoken and used by the people all over the world. Some linguists have underlined the importance of developing communicative competence-especially speaking skill-in language teaching. Tompkins \& Hoskisson (1995) state that the most important general goal in language instruction is to help students learn to communicate effectively with others through oral and written languages, and mastering the art of speaking is the single most important aspect of learning a second or foreign language, the success of which is measured in terms of the ability to carry out a conversation in the language.
Concerning the importance of mastering the communicative competence of English based on some linguists' perspective, the national policy through the regulation of minister of national education no 22, 2006, reflects the importance of English in the standard of content. In this case, English is taught as a compulsory subject for senior high schools in Indonesia that is the instruction should be focused on the teaching of the four language skills. According to the standard of competence for the speaking skills, senior high school students are expected to be able to express meaningful ideas for both simple transactional (to get something done or get the information) and interpersonal (to get in touch with others for social purposes) communication to interact with people in their nearest 
environment (Depdiknas, 2006). The students at this level-senior high schoolsare targeted to achieve the informational level that is to be able to communicate orally and in written form to find information (Depdiknas, 2006).

Dealing with the expectation of the objective in speaking skill is not easy and simple, either for the teachers or for the students. They face some difficulties in the teaching and learning of speaking. Based on the researcher's experience and observation in classroom activities, the researcher found some problems. First, students felt afraid and nervous when they wanted to speak or communicate using English in front of their classmates. Second, the students did not have any idea or initiative to speak unless he asked them questions, or when they had ideas, they did not know how to express the ideas. It was due to the lack of vocabulary, lack of understanding of grammatical patterns, and lack of practicing English speaking. Third, the students still frequently made mistakes in pronuncing the English words. It was caused by their pronunciation which was still influenced by their native language. Fourth, their problem with prosodic features such as intonation, stress, and other phonological nuances still caused misunderstanding or led to communication breakdown. Those problems made the students reluctant and unmotivated to speak.

Based on the problems above, the researcher found the evidence that the students' speaking ability is still unsatisfactory. The researcher got this evidence from the English teacher who teaches $X 9$ grade. It was found that the students' average score for speaking 50.15- was still below 75 as the passing grade (Kriteria Ketuntasan Minimum-KKM). There were only seven students, out of thirty-five students who had achieved the passing grade.

In order to solve the students' problem and enhance their speaking ability, a teacher has to be able to provide some techniques that can involve students in practicing speaking and also give motivation. The EFL teachers should create a classroom environment where students have real-life communication, authentic activities, and meaningful tasks that promote the use of oral language. Nunan (1991) says that teachers should help their students by establishing strategies to manage all forms of communication to ensure that all students have fair and equitable opportunities to develop their interpersonal speaking and listening skills, e.g. Through large and small group discussions. Dealing with the reality, the English teacher is supposed to apply more challenging techniques in teaching. The teaching will be more interesting if the teachers can create fun activities by applying some kinds of techniques that fit the students' level.

In EFL teaching, a teacher should create a classroom environment where students have real-life communication, authentic activities, and meaningful tasks that promote the use of oral language. Nunan (1991) says that teachers should help their students by establishing strategies to manage all forms of communication to ensure that all students have fair and equitable opportunities to develop their interpersonal speaking and listening skills, e.g. Through large and small group discussions. Dealing with the reality, the English teacher is supposed to apply more challenging techniques in 
teaching. The teaching will be more interesting if the teachers can create fun activities by applying some kinds of techniques that fit the students' level.

Retelling story made the speaking activity became joyful since it could help students tell the cronological events of the story easily. Through story-retelling technique, students can demonstrate their comprehension of the story. Vale \& Feunteun (1995) state that story-retelling is a technique or an approach in teaching language. It demonstrates the value of practical tasks as social, motivational, and language teaching tools in the learning situation. It also makes students enjoy learning language.

Picture series also can be used as media in the teaching speaking. Using picture in teaching has some advantages. Beside that pictures can translate abstract ideas into more realistic form, can be easily obtained, can be used in different academic levels, can save teacher's time and energy, and can attract student's interest. Students who use pictures to tell stories free themselves from what they are saying. The joyful learning brought into the classroom through the pictures can really liven up the learning experience.

Speaking is considered as a very important aspect of learning a foreign language. Burns \& Joyce (1999) say that most language programs aim to integrate both spoken and written languages but the emphasis is given to speaking. The emphasis that is given to speaking in a language program varies according to the needs and goals of the students and the focus of the course. Moreover, Richard \& Renandya (2002) state that a large percentage of the world's language learners study English in order to develop proficiency in speaking.

In addition, Burns \& Joyce (1999) mention that one of the most important aspects of speaking is that it always occurs within context. When we speak we are both using language to carry out various social functions and choosing forms of language which relate in a relevant way to the cultural and social context. When the teachers want to make their students communicatively competent in English as a foreign or second language, it is justifiable to say that speaking will play a large part in the overall competence.

Technique is very important in teaching and learning process. It has a very essential role in supporting the success of teaching and learning process. According to Brown (2001), techniques are the specific activities manifested in the classroom. In other words, a technique is about any of a wide variety of exercises, activities, or tasks in the language classroom used to achieve the objectives of the lessons. There are a number of techniques which can be used to ensure that students not only understand the meaning of a language form but they are also able to use it in exchanging or producing ideas and feelings. One of the techniques that can be used and applied in classroom activities is a story-retelling. Additionally, Wendelin in Farris (1993) said that engaging students in storyretelling activities develop communication skills and encourages shared learning experiences. Retelling stories enhances oral language and sharpen listening. Speaking ability is improved through attention to articulation, clarity, and volume. Poise and confidence in speaking before a group are required in the 
accepting environment of the classroom. Students experiment with various intonations and reflect a range of emotions in their voices. They are faced with the need to select just the right word to convey a thought. As they manipulate language, they also listen to, evaluate and appreciate the expression of others.

In pedagogical theory there are strong supports for story-retelling to be used in language teaching. Cruz (2001) explains that the story-retelling as an ancient oral art can demonstrate the power of words. It artistically uses language to develop the entire critical component involved in the communication process, develops listening skill, enhances verbal expression, increases comprehension, and creates mental images. Story-retelling is an excellent means of developing speaking skills.

In the teaching narrative text using story-retelling, teacher can use several techniques to make the story come alive as it is told. One of them is using picture series. In retelling a story, students can employ some pictures which show the characteristics involved in it, the setting of the story, and the plot of the story. Students can tell the story on the bases of the series of pictures they get.

Story-retelling is an ancient art that is a valuable instructional tool. Teacher shares literature with their students using storyretelling techniques and students tell stories too. Story-retelling is entertaining and stimulates children's imaginations. It expands their language abilities, and it helps them internalize the characteristics of stories and develop interpretations of stories (Morrow in Tompkins \& Hoskisson, 1995).
In line with the teaching narrative text using story-retelling, teacher can use several techniques to make the story come alive as it is told. One of them is using picture series. In retelling a story, students can employ some pictures which show the characteristics involved in it, the setting of the story, and the plot of the story. Students can tell the story on the bases of the series of pictures they get.

After getting the narrative text, students can begin their story retelling by seeing the picture which shows the introduction of the story as they read in the narrative text. After that they can go to the next pictures to continue the story. The students can do such kind of activities until the end of the story.

Shortly, picture series is intended help students to tell the story besides, it is expected to promote their motivation to speak. Therefore, this research is conducted to solve the students' problems in speaking. It is to improve the students' ability in speaking through story-telling technique by using picture series in terms of content and delivery of the story.

\section{METHOD}

The study utilized classroom action research developed by Kemmis \& Mc. Taggart in Koshy (2005) since it focuses on a particular problem and a particular group of students in a certain classroom. The classroom action research in this study is directed to develop a strategy to solve the classroom problems specifically in teaching speaking since it is very important for the researcher to develop a suitable technique to improve the speaking ability of Grade $X$ students of MAN 2 Madiun. By applying this design, it was expected that the teacher can solve 
the problems faced in the classroom by implementing the technique in the teaching-learning process of speaking.

The subject of this research is Grade $X$ which consists of 32 students of the second semester in the 2014/2015 academic year. This class was chosen based on the teacher's and researcher's problem as the English teachers at this school. The researcher once taught the students of this class and he observed that the students in this class faced some problems in speaking. The students' score on speaking skill is still under the passing grade, 75 . The result of preliminary study showed that the average score of the students' speaking skill was 50.15.

Criteria of success are set up to determine whether the action in the research is successful or not which are emphasized on the process and the product of the teaching-learning activities. This action research is considered to be successful if it meets the following criteria: (1) If $70 \%$ of the students participate or are actively involved in the teaching-learning process from reading activity to speaking activities. This implies that the action is successful, (2) If the students'mean score was greater than or equal to 75 . This means that the students' speaking ability in terms of their proficiency in producing English (narrative texts) improved and was considered successful because of the applied technique. The students' performance in retelling a story using picture series in front of the class was assessed by using two scoring rubrics, it was aimed at seeing the students' speaking and delivery performance, (3) If $70 \%$ or more of students have good responses to the implementation of the story-retelling technique using picture series. In this case, the students choose the preferred options (sangat setuju/setuju) for the answer of each item in the questionnaire. This means that the study is successful.

\section{FINDINGS AND DISCUSSION}

Based on the result of the speaking test (story-retelling performance) which was conducted within speaking class, there was an improvement of the students' mean score from the pre-test to the test 1 . The mean score of the preliminary test was 50.15 while the mean score cycle 1 was 68.5 . It means that there was slight improvement on the mean score when it was compared with the mean score of preliminary test. From that score, it could be said that the improvement was approximately 1.8 . \%. The detailed data about the improvement of the students' speaking mean score could be elaborated as follows: 10 students or $32 \%$ out of 32 achieved the score equal to or greater than 75 or met passing grade. Meanwhile, the other 22 students or $68.8 \%$ out of 32 achieved the score 60.80-73.50. From that data, it could be known that all students' score improved when it was compared with the preliminary test. However, the score improvement did not meet the criteria of success yet since there were merely $32 \%$ students out of 32 who gained score equal to or greater than 75 as the passing grade creterion.

Besides, the data obtained from the observation checklist showed that the students actively participated in the teaching-learning process. During the three meetings of the process of teaching and learning of speaking, most of students fully paid attention to the teacher's 
explanation. The students were excited in asking and answering questions toward the stories, For reading a story of the Lion and the Mouse in cycle 1 , it was found that 13 students (40.6\%) were very active (VA); as they met six to seven of the indicators in the observation checklist, 6 students (18.8\%) were active (A) as they met four to five of the indicators, 2 students $(6.3 \%)$ were active enough (AE) as they met tree of the indicators, and 7 students $(21.8 \%)$ were not active (NA) as they met only two of the indicators. 3 students were absent in this meeting. From these data, it could be stated that there were 18 students $(56.3 \%)$ who were categorized as active participants -very active plus active- and who were actively involved in the teaching-learning process.

In cycle 2, The result of the analysis -students' performance- showed that the improvement of students' average score was higher than the average score in the preliminary study. It revealed that 10 students (32\%) obtained a score of equal to and/or higher than 75 and 12 students $(37.5 \%)$ got scores below 75 . Based on the result of the students' performance (retelling a story), the average score was 68.5 and the average score in the preliminary study was 50.15 . This means that the improvement of score was $26.8 \%$. Besides the improvement of score in cycle 2 has met the criteria of success, it was $70 \%$ of the students got score equal to or greater than 75 . There were $72 \%$ students or 24 whose score met the minimum criterion of learning success or (KKM) since the average score was 77.6. So when it was compare with the preliminary study the improvement was about 31\%. The improvement of students' achievement can be seen in the following figure.

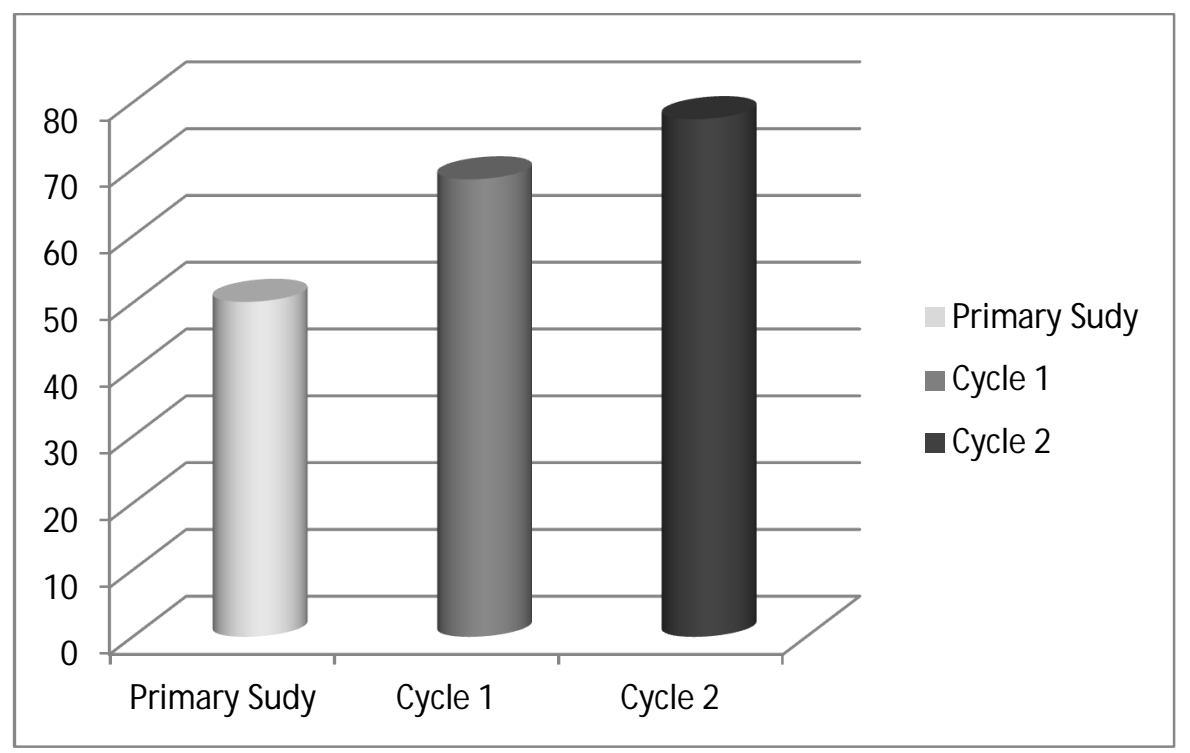

\section{Figure 1. The Improvement of Students' Speaking Score}

The implementation of the strategi in teaching speaking also can improve the students' involvement within the instructional process. In cycle 1,56.3\% of the students were actively involved in the teaching and learning process, while in cycle 2 , it was $84 \%$ of the students. It means that the improvement of the 
students' involvement from cycle 1 to cycle 2 was $2.8 \%$. In detail, the improvement of students' participation in following the classroom activities during the implementation of story retelling using picture series to enhance students' speaking ability can be seen in the following Figure.

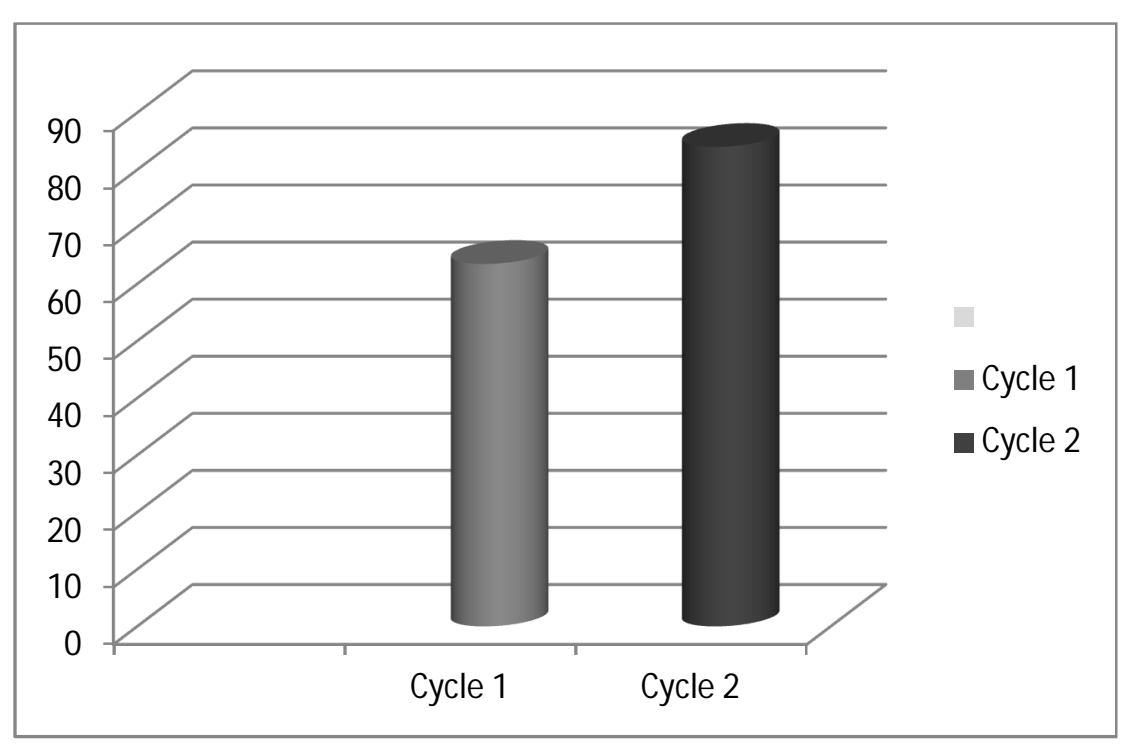

Figure 2. The Improvement of Students' Participation During the
Implementation of the Technique

In regards to the improvement of the students' involvement in the speaking session specifically related to the activity of pronouncing the English words fluently and acurately, there was no improvement from cycle 1 to cycle 2 since the number of the active students was the same. It was $68.6 \%$. On the other hand, after going through cycle 2, there was slight improvement. It became $8.9 \%$ of students participated in teaching-learning process. It means that the improvement from cycle 1 to cycle 2 was only $6 \%$.
Based on research finding, it is said that the implementation of story-telling strategi had met the criteria of success, this study is said to be successful as described in the summary of the findings presented in Table 1. More detailed description of the research findings can be seen in the following three sub-sections respectively referring to the students' participation, the students' speaking achievement, and the students' responses to the technique. 
Table 1. The Description of the Criteria of Success and the Findings of the Study

\begin{tabular}{|c|c|c|c|}
\hline No. & Criteria of Success & Findings of the Study & Note \\
\hline 1. & $\begin{array}{l}70 \% \text { of the students or more } \\
\text { participate or are actively } \\
\text { involved in the teaching- } \\
\text { learning process. }\end{array}$ & $\begin{array}{l}84 \% \text { students did four to } \\
\text { seven indicators listed in the } \\
\text { observation checklist } \\
\text { meaning that the students } \\
\text { were actively involved in the } \\
\text { teaching- learning process. }\end{array}$ & The criterion was achieved. \\
\hline 2. & $\begin{array}{l}\text { If the students' mean score } \\
\text { was greater than or equal to } \\
75 \text { as the minimum mastery } \\
\text { criterion for the English } \\
\text { subject. }\end{array}$ & $\begin{array}{l}\text { The students' mean score } \\
\text { was } 77.6\end{array}$ & The criterion was achieved. \\
\hline 3. & $\begin{array}{l}70 \% \text { of students have good } \\
\text { responses to the } \\
\text { implementation of the story- } \\
\text { retelling technique using } \\
\text { picture series. }\end{array}$ & $\begin{array}{l}89 \% \text { of the students showed } \\
\text { good or positive responses to } \\
\text { the technique. }\end{array}$ & The criterion was achieved. \\
\hline
\end{tabular}

The finding of this study has proven that story-retelling technique can improve the students speaking ability. It can be seen from the improvement of the students' score. The students' average score in the starting point (preliminary study) was 50.15. After the implementation of the story-retelling technique using picture series as media, it became 74.5 . In other word, $72 \%$ students already achieved scores greater than 75 as the criterion of success determined. Besides, improving the students' score, this technique can also increase the students' involvement; it was found that $84 \%$ students were actively involved in the teaching learning process, and $89 \%$ of the students showed good or positive responses to the technique. Hence, the story-retelling technique using picture series can be used as one of the alternative instructional media in the classroom.

In regard to the use of media (picture series), they really helped both the teacher and the students. They facilitated students' learning activity that made the activity more interesting. It can be seen that the students enjoyed some activities and they were motivated to be involved in the activities during the implementation of the technique.

\section{CONCLUSION}

On the basis of the findings of the data analysis, it can be concluded that the story-retelling technique using picture series is successful in improving not only the students' participation in the teachinglearning process but also the speaking ability of the students in terms of retelling a story or in this case, students' score and their interest in learning English. The use of media (picture series) really assisted both the teacher and the students. They facilitated students' learning activity that made the activity more interesting. The success was indicated by the achievement of the criteria of success which deal with the students' involvement in the teaching- 
learning process; it was found that $84 \%$ students were actively involved in the teaching-learning process. Concerning the students' scores, it showed that $81 \%$ of the students already achieved scores greater than 75. The last, the students' responses to the implementation of the technique revealed that $89 \%$ of the students showed good responses to the technique.

The story-retelling technique using picture series in teaching speaking encompasses several procedures: 1) understanding the narrative text carefully, 2) understanding grammar and difficult words, 3) employing dictions based on its context, 4) discussing the text in groups, 5) using own sentences to deliver story, 6) avoiding mistakes by having picture series, 7) understanding the message or social value of the text, and 8) giving reward to enhance motivation.

To follow up the findings, some suggestions are addressed to the English teachers, the school principal, and the future researchers. English teachers are recommended to utilize the technique in the teaching-learning of speaking or other skills such as listening and writing. The

\section{REFERENCES}

Brown, H.D. (2001). Teaching by Principles: An Interactive Approach to Language Pedagogy ( $2^{\text {nd }}$ ed.). New York: Addison Wesley Longman Inc.

Burns, A. \& Joyce, H. (1999). Focus on Speaking. Sydney: Macquarie.

Cruz, T.C. (2001). Enhancing Literacy through the Techniques of Storytelling, (Online). Retrieved August 14th 2008, from http://www.asha.org/about/public ations /eader- story-retelling technique can be applied to teach some genres such as recount and narrative, because it is a natural way to learn a new language where people always tell something to everyone else, and it happens commonly.

It is suggested for the principal to provide facilities to improve the students' ability in learning English especially speaking, and conducts the events such as story retelling using picture series competition is worthwhile to elevate the students' interest and motivation in learning English. The school principal can supply the materials to make some media that can be used in teaching-learning activities like the materials for making picture series.

To the future researchers, particularly those who are interested in applying story-retelling technique using picture series, it is suggested to conduct classroom action research or other designs on the use of this technique in the teaching of other language skills, for instance listening and writing and also other types of genre.

online/archieves/2001/storytelling. html

Depdiknas. (2006). Regulation of Minister of National Education. Indonesian Republic No. 22 Year 2006, Content Standard for Primary and Second Year at English Subject. Jakarta.

Farris, P.J. (1993). Language Arts: A Process Approach. Illinois: Brown \& Bechmark Publishers.

Koshy, V. (2005). Action Research for Improving Practice: A practical Guide. London: SAGE Publication. 
Nunan, D. (1991). Language Teaching Methodology: A Textbook for Teachers. New York, UK: Prentice Hall International.

Richards, J.C. \& Renandya W.A. (Eds.). (2002). Methodology in Language Teaching: An Anthology of Current Practice. Cambridge: Cambridge University Press.

Tompkins, G.E., \& Hoskisson, K. (1995). Language Arts: Content and
Teaching Strategies. New Jersey: Prentice-Hall.

Vale, D. \& Feunteun, A. (1995). Teaching English Children. Cambridge: Cambridge University. 